\title{
Housing of Pregnant Sows in Loose and Confined Systems - a Field Study 1. Vulva and Body Lesions, Culling Reasons and Production Results
}

\author{
By H. Gjein ${ }^{1}$ and R. B. Larssen ${ }^{2}$
}

${ }^{1}$ Norwegıan Pig Health Service, Central Veterınary Laboratory, Oslo, and ${ }^{2}$ Department of Large Anımal Clınical Sciences, Norwegian College of Veterinary Medicine, Oslo, Norway.

\begin{abstract}
Gjein, H. and R. B. Larssen: Housing of pregnant sows in loose and confined systems a field study. 1. Vulva and body lesions, culling reasons and production results. Acta vet. scand. 1995, 36, 185-200. - A field study was carried out in 18 herds with loose housing of pregnant sows (loose herds) and in 18 herds with tethered or stalled pregnant sows (confined herds). Three of the loose herds were excluded due to different kind of flooring from the rest of the herds. The remaining 15 herds had partly slatted concrete floors and electronic sow feeding The frequencies of sows with vulva and body lesions, thin sows as well as the culling reasons and production results were used as animal welfare indicators for the herds. Vulva lesions were found only in the loose herds and the mean prevalence proportion of sows with lesions within these herds was $15.2 \%$ All vulva lesions observed in this study seemed to be caused by bitıng. The relative risk of vulva lesions was 2.6 times higher in the loose herds with no roughage feeding as compared to loose herds with appetite feeding of roughage. The sows in the loose herds, that had a feeding station with a mechanical hind gate had 1.8 greater risk of vulva lesions than sows in the loose herds that used a feeding station with an electronic gate.

The mean prevalence proportion of sows with body lesions was $13.1 \%$ in the loose herds and $4.0 \%$ in the confined herds. Aggression between sows seemed to be the main cause of body lesions in the loose herds, while decubitus ulcers on the shoulders were the main cause of body lesions in the confined herds. Sows in loose herds that were not fed additional roughage feeding had 1.7 times greater risk of body lesions than sows in herds that used additional roughage feeding.

The main culling reasons and production results were similar in the loose and confined herds. This study showed that there were welfare problems both in confined and loose herds, however, with improved management, many of the welfare problems associated with loose housing can be reduced.
\end{abstract}

welfare; health; electronic feeding; slatted floors; roughage feeding; epidemiology.

\section{Introduction}

Confined systems for sows are associated with welfare problems. Sows that are tethered or stalled have a higher frequency of stereotypic behaviour (Ekesbo et al. 1979), more lameness and leg weakness (de Koning 1985,
Svendsen \& Olsson 1985) and prolonged farrowing (Svendsen \& Olsson 1985) than sows in group housing.

Loose housing of pregnant sows has been established to improve the well-being of sows and also because loose housing is less expen- 
sive than other housing systems. Sows in loose housing are able to act more naturally than in confined systems. They can move freely around, engage in social behaviour and determine their own lying place (van Putten \& van de Burgwal 1990a).

However, housing of pregnant sows in large groups ( $\geq 15$ sows) has now been practised for some years, and the disadvantages of the system have become more clear, especially when loose housing is combined with use of an electronic feeding station and slatted floors. Pigs are social animals that prefer to eat in groups, but the housing of the sows in groups will often produce aggressive behaviour resulting in fight lesions to the vulva and body. This situation is aggravated if the sows are housed in a pen with slatted floors and if there are few stimuli in the environment other than feeding at a station once a day (Svendsen et al. 1990, van Putten \& van de Burgwal 1990a). Lameness, claw lesions, vulva lesions, aggression, and lesions on the body are the problems most frequently reported (de Koning et al. 1990, Svendsen et al. 1990, van Putten \& van de Burgwal 1990a, Olsson et al. 1991, Kroneman et al. 1993).

Evaluation of housing systems with regard to welfare has been performed both in field studies and under more controlled situations on research farms. The welfare parameters that have been used are behavioural characteristics, free cortisol in the blood, lesions, disease frequencies and production results (de Koning 1985, Hunter 1990, Barnett et al. 1992).

The present study was part of a larger field investigation that was conducted to study the relationship between different housing of sows, and health and welfare, with special emphasis on claw lesions. In the present study the objectives were to compare some animal welfare indicators under field conditions in herds with loose and confined housing of pregnant sows, and to study the effect on welfare of differences in environment and management within the loose housing herds. The impact of housing on claw health and lameness will be described in later papers.

\section{Materials and methods}

\section{Design}

The study was a prospective open cohort study (multiple cross sectional) in 36 herds during a period of 12 months with animals leaving or entering the herds at any time. All sows in the farrowing and pregnant sow compartments in the herds were subject to 3 clinical examinations i.e. in October 1989, April 1990 and October 1990.

\section{Selection of herds - reference population}

A stratified random sample from all farrowing herds within a radius of $150 \mathrm{~km}$ from Oslo was taken. To be included in any of the cohorts, a herd had to :

* have new houses or rebuilt houses, i.e. new floors, within the last 5 years.

* be a member of the Norwegian sow recording scheme.

* have been in business for at least 1 year.

* have an owner who was willing to participate and do the necessary registrations.

* have a veterinarian who was willing to participate and do the necessary registrations.

The inclusion criterium new floor was used to prevent system differences resulting from the age of the floor, because all loose housing herds had new floors within the last 5 years. The sampling frame was a list from the regional abattoirs of all loose $(\mathrm{N}=45)$ herds and all confined $(\mathrm{N}=50)$ herds in the region that had installed new floors within the last 5 years. Three herds, 2 loose and 1 confined, were not included because the owners were unwilling to participate. 


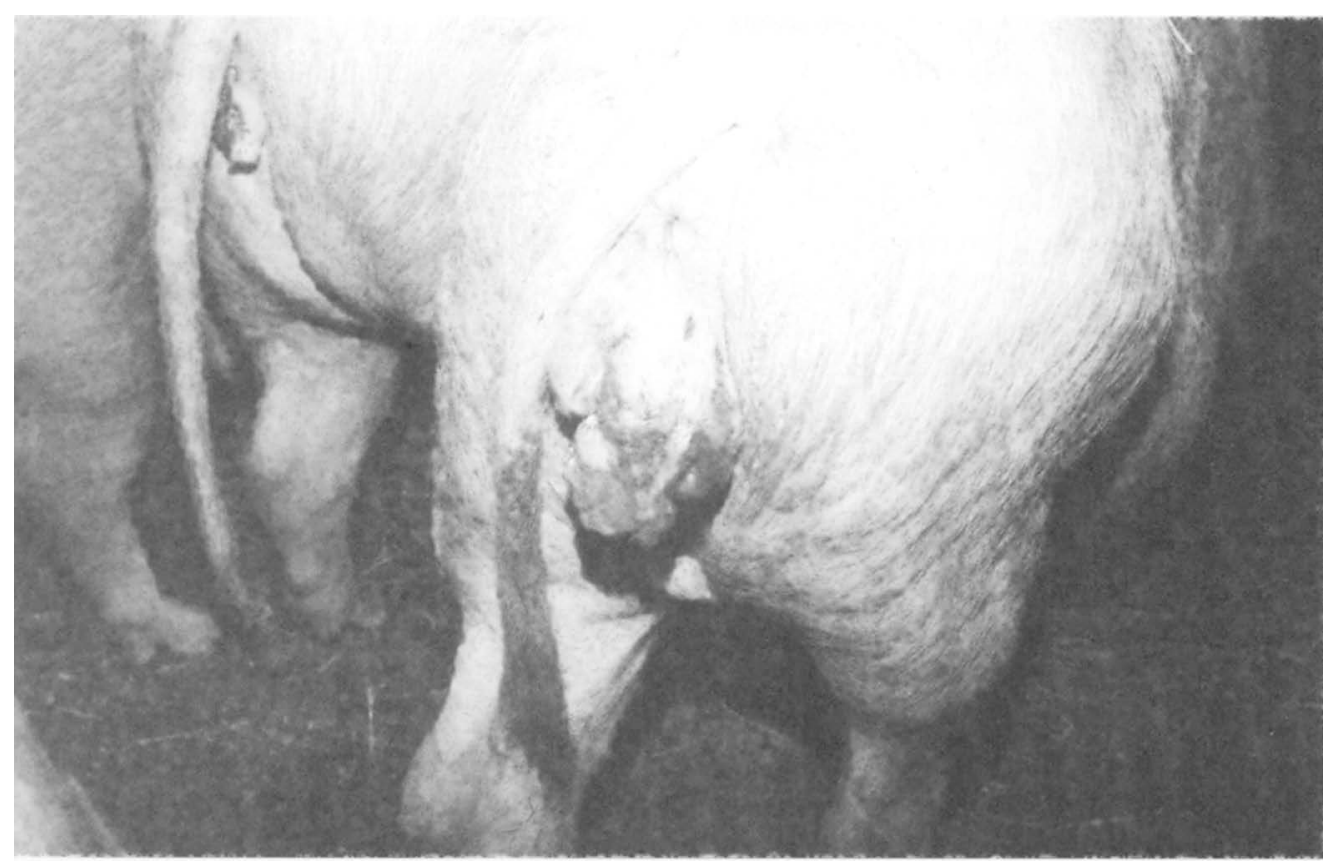

Figure 1. A serious vulva lesion.

\section{Loose herds}

The "loose" cohort included 18 herds and was sampled from the stratum consisting of herds with loose housing of pregnant sows. Fifteen of the loose herds had partly slatted concrete floors without or with very little bedding and electronic sow feeding. Average number of year-sows in these 15 herds was 39.2 (26-70), and the group size of pregnant loose sows was between 15 and 40 . One year-sow is the equivalent of a sow older than 6 months that spend a complete year in the herd; however, only sows that subsequently farrow are included.

One loose herd had deep litter based on straw, 1 had a concrete floor without slats and partly deep litter with sawdust, and 1 changed from partly slatted floor to deep litter during the study period (after the April 1990 examination). The 2 herds with deep litter were excluded from the analysis because of the differ- ence in flooring to the 15 herds with partly slatted concrete floors, and the pronounced effect that deep litter flooring apparently has on sow health. The third herd was excluded due to the change of flooring.

\section{Confined herds}

Cohort confined herds included 18 herds and was sampled from the stratum consisting of herds with confined housing of pregnant sows. Twelve herds had stalled sows and 6 herds had tethered sows. Average herd size was 30.1 year-sows (17-53).

\section{Management and feeding}

The loose herds had dynamic groups of pregnant sows, except 1 herd that had integrated loose housing, where the pregnant and suckling sows were in the same group. However, 
also in this herd, the weaned sows were held separately in a period after weaning. In the dynamic groups of pregnant sows, 3-5 new sows were released simultanously into the loose house compartment 3 weeks after service or, in some cases, directly after weaning at 5 weeks. Young sows that had not farrowed (gilts) were also usually released into the group 3 weeks after service.

Electronic sow feeding was practised in all the loose herds, using 1 of 2 different types of electronic feeding station. One type had a hind gate that closed mechanically (5 herds) when the sow came into the automat. The other type had a hind gate that closed electronically ( 10 herds) when the automat "read" the transponder of the sow and was thus closed only if and when the sow received feed. Six of the feeding stations had solid side walls, while 9 of the stations had walls made of metal bars. The type of side walls was independent of the type of hind gate. Five of the loose herds had a water nipple inside the feeding station, so the sow received the feed mixed with water. In the other 10 loose herds, the sows only received dry feed in the feeding station. In 7 herds, the sows could receive all the daily feed during one visit in the feeding station, and in 8 herds, the sows were fed twice a day.

Additional roughage feeding was used both in some of the loose and some of the confined herds. Different kinds of roughage were used including hay, straw, silage, turnips, potatoes or a combination of these.

\section{Clinical examinations}

All herds were visited 3 times at 6 months intervals. All sows were examined at each visit for lesions and body condition. Both vulva and body lesions were recorded as present or absent.

Vulva lesions = lesions on the vulva.
Body lesions = lesions on the body, head, legs above the feet and shoulder lesions (decubitus ulcers on the shoulders).

The body condition was scored as thin (score $=1$ ), normal $($ score $=2$ ) or fat $($ score $=3$ ).

The frequencies of sows with vulva lesions, body lesions, and thin sows as well as culling reasons and production results were used as animal welfare indicators.

\section{Records}

The amount of roughage feeding in the herds was recorded and divided in 3 classes: Free access to roughage (appetite), some roughage and no roughage.

The farmers recorded all cullings. The main culling reason for each sow was classified as reproduction failure (returns, empty sows, no heat), locomotor problems (lameness, claw lesions, back injury), inadequate performance (small litters, poor mother), age/low index or other reasons.

The production results were obtained from the Norwegian sow recording scheme. The farrowing date and examination date were used to group the sows in monthly periods after farrowing.

\section{Statıstical methods}

Unless otherwise stated, the following measures of disease on a herd level were used: Prevalence $=$ The arithmetic mean of the prevalence of sows with the lesion in the herd at the 3 examinations. Cumulative prevalence proportion $=$ The cumulative proportion of sows in the herd that had the lesion on at least 1 of the 3 examinations.

The sow observations used in this paper were 3 repeated examinations of the same variables. Thus dependency existed both between the examinations within animals and between the animals within a herd. This was taken care of during the analysis. The data are presented 


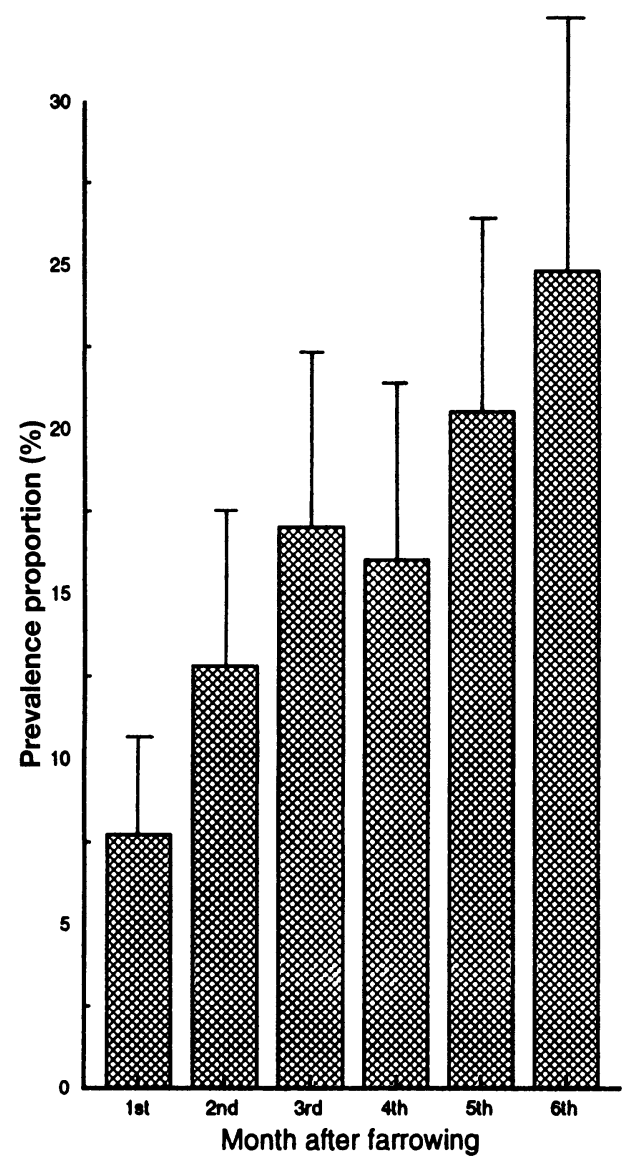

Figure 2. Mean prevalence proportion (with 95\% CI) of sows with vulva lesions in relation to tıme after farrowing in loose herds (no loose sow observations $=1129$ ). However, 307 were not included in the figure due to not having farrowed (gilts $=300$ ) or missing values $(7)$.

and analysed using either sow observation, claw, animal or herd as the unit of concern depending on the question to be answered. Herd was used as unit in the statistical analysis except in the description of the relationship of vulva lesions, body lesions and body condition with number of litters (Figs. 3, 5 and 6), and with time after farrowing (Figs. 2 and 4). In these presentations, sow observation was treated as an independent observation and used as unit. No statistical hypothesis testing was carried out using sow observation as unit since the observations were not statistically independent, however, the $95 \%$ confidence intervals $(\mathrm{CI})$ of the group means are marked in the figures.

Relative risks with $95 \%$ CI were calculated using EpiInfo (Dean et al. 1990). All other analyses were made using SAS version 6.04 for DOS (SAS Institute Inc. 1989). 
The effects of environmental factors were analyzed both using simple one way ANOVA and using a multivariate model with all relevant factors in the model (PROC GLM in SAS). This model takes into consideration the influence of all the environmental factors simultaneously. Model specification for GLM multivariate analysis for vulva lesions and body lesions respectively :

$y=\mu+a_{1}+b_{j}+c_{k}+e_{1 j k}$, where

$\mathrm{y}=$ mean herd prevalence of vulva lesions (/body lesions).

$\mu=$ overall mean.

$\mathrm{a}_{1}$ = roughage feeding

( $1=$ appetite, $2=$ some, $3=$ none $)$.

$\mathrm{b}_{\mathrm{j}}=$ feeding station hind gate

( 1 = mechanical, 2 = electronic) .

$c_{\mathrm{k}}=$ feeding station walls

( 1 = bars, 2 = solid $)$.

$\mathrm{e}_{\mathrm{j \textrm {k }}}=$ random error.

\section{Results}

\section{Vulva lesions}

Vulva lesions were found only in the loose housing herds, and all vulva lesions observed in this study seemed to be caused by biting (Fig. 1). The mean prevalence proportion of sows with vulva lesions in the loose herds was $15.2 \%$, but with a great variation between herds from a minimum of $2.4 \%$ to a maximum of $43.2 \%$. The mean cumulative proportion of sows with vulva lesions was $21.2 \%$ (4.3$53.7 \%$ ).

The clinical examinations showed that the vulva lesions varied in severity. The vulva lesions often appeared to be inflamed, however, the inflammation seemed to be superficial and local. Serious complications involving the vulva lesions were not observed or reported. The prevalence proportion of sows with vulva lesions increased from farrowing to the end of gestation (Fig. 2). The vulva lesions recorded on the sows in the farrowing compartment were old lesions that the sows had received in the loose housing compartment. Gilts showed a tendency to have less vulva lesions than the sows with 1 or more litters (Fig. 3).

The relative risk of vulva lesions was related to environmental factors (Table 1). The relative risk of vulva lesions was 2.6 times higher $(\mathrm{p}<0.05)$ in the herds with no roughage feeding as compared to appetite feeding. It was observed that, in herds with roughage feeding, the sows appeared to be less hungry than in the herds with only concentrate feeding. The farmers from the herds with additional roughage feeding reported that the sows ate the concentrate feed in the feeding station throughout the day. The sows in these herds did not stand in line behind the station in the morning when the feeding started as much as they did in the herds with no additional roughage feeding.

The sows in the herds that had a feeding station with a mechanical hind gate had 1.8 times greater risk $(\mathrm{p}<0.05)$ of vulva lesions than the sows that used a feeding station with an electronic gate. The crude means indicated that the herds with bar walls in the feeding station had a greater risk of vulva lesions than herds with solid walls; however, the LS means did not show a difference. There was no association between prevalence of vulva lesions and 1 versus 2 feedings a day, or between prevalence of vulva lesions and access versus no access to water in the feeding station.

\section{Body lesions}

Body lesions were either lesions on the body caused by aggression between the sows, decubitus ulcers on the shoulders, or lesions caused by the equipment and environment. The lesions resulting from aggression were located on the head, the shoulders, and the hips, and were, to a great extent, superficial with- 


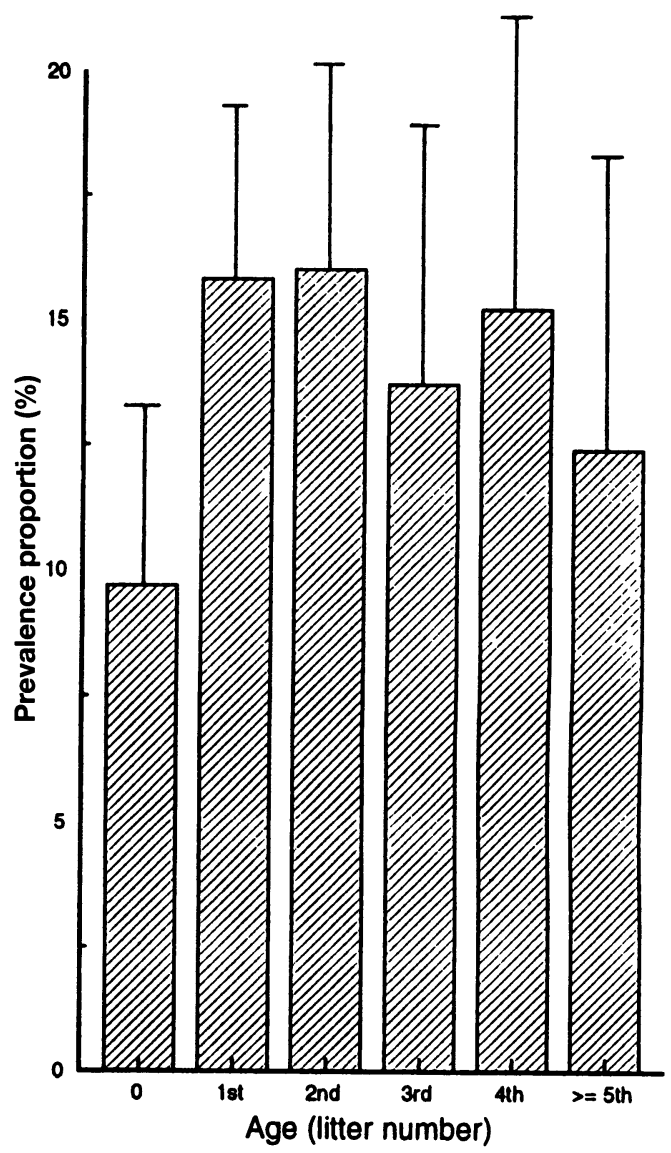

Figure 3. Mean prevalence proportion (with $95 \% \mathrm{CI}$ ) of sows with vulva lesions in relation to number of litters in loose herds (no. loose sow observations $=1436$ ).

out complications, although abscesses in the skin were seen in a few cases. The mean prevalence proportion of sows with body lesions was $13.1 \%$ in the loose herds and $4.0 \%$ in the confined herds. The mean herd cumulative prevalence proportion of sows that had body lesions was $15.8 \%(3.7-29.6 \%)$ in the loose herds and $6.1 \%(0-24.4 \%)$ in the confined herds.

Only 3 of the confined herds had higher than $5 \%$ prevalence of body lesions. In 2 of these herds, most of the lesions were decubitus ul- cers and, in the third herd, the nature of the body lesions indicated that the lesions on the legs were caused by slats with sharp edges. The nature of the body lesions in the loose herds indicated that the majority of the lesions resulted from aggression between sows. Only $13 \%$ of body lesions in the loose herds were classified as decubitus ulcers, while $58 \%$ of body lesions in the confined herds were decubitus ulcers on the shoulders.

In the loose herds, body lesions on the sows were most frequently found during the initial 
Table 1. Vulva and body lesions in relation to roughage feeding and type of feeding station within loose herds. Cumulative prevalence proportion of sows in each herd that had vulva or body lesions on at least 1 of the 3 examinations.

\begin{tabular}{|c|c|c|c|c|c|c|c|c|c|c|c|}
\hline \multirow{2}{*}{$\begin{array}{l}\text { Environmental } \\
\text { factor }\end{array}$} & \multirow{2}{*}{$\begin{array}{c}\mathrm{N} \\
\text { (herds) }\end{array}$} & \multicolumn{5}{|c|}{ Vulva lesions } & \multicolumn{5}{|c|}{ Body lesions } \\
\hline & & $\overline{\mathrm{X}}^{1)}$ & Min & $\operatorname{Max}$ & $\begin{array}{c}\text { LS- } \\
\text { mean } \%^{2)}\end{array}$ & $\mathrm{RR}^{3)}$ & $\overline{\mathrm{x}}$ & Min & $\operatorname{Max}$ & $\begin{array}{c}\text { LS- } \\
\text { mean \% }\end{array}$ & RR \\
\hline \multicolumn{12}{|c|}{ Roughage feeding: } \\
\hline - Appetıte & 5 & 13.8 & 4.3 & 23.7 & 14.2 & 1.0 & 14.6 & 8.5 & 25.5 & 13.0 & 1.0 \\
\hline -Some & 5 & 15.5 & 5.2 & 30.4 & 20.5 & 1.4 & 14.5 & 3.8 & 21.1 & 16.1 & 1.2 \\
\hline - None & 5 & 34.4 & 21.1 & 53.7 & $37.5^{*}$ & 2.6 & 182 & 10.7 & 29.6 & 21.8 & 1.7 \\
\hline \multicolumn{12}{|c|}{ Feeding station, hind gate: } \\
\hline - Mechanical & 5 & 31.5 & 22.7 & 53.7 & $31.0^{*}$ & 1.8 & 18.1 & 10.7 & 29.6 & 18.6 & 1.2 \\
\hline - Electronic & 10 & 16.1 & 4.3 & 41.1 & 16.8 & 1.0 & 14.6 & 3.8 & 25.5 & 15.3 & 1.0 \\
\hline \multicolumn{12}{|c|}{ Feedıng station, walls: } \\
\hline - Bars & 9 & 25.1 & 5.2 & 53.7 & 22.2 & 1.0 & 15.2 & 3.8 & 29.6 & 13.7 & 1.0 \\
\hline - Solid & 6 & 15.5 & 43 & 23.7 & 25.6 & 1.2 & 16.7 & 9.8 & 25.5 & 20.1 & 15 \\
\hline All herds & 15 & 21.2 & & & - & - & 15.8 & & & - & \\
\hline
\end{tabular}

1) Mean cumulative prevalence proportion.

2) The LS-mean is the mean when the confounding effect of the other two environmental factors in the table have been accounted for.

3) Relative risks (RR) are based on LS-means.

* The group was significantly different $(\mathrm{p}<0.05)$ from the other(s) with regard to the environmental factor.

period after they were released into the loose housing compartment (2nd and 3rd month in Fig. 4).

The age pattern of body lesions was different in loose sows compared to confined sows. In the loose herds, the sows with 1 litter had most lesions on the body, while the older sows and gilts had less body lesions (Fig. 5). In the confined herds, the prevalence of body lesions increased with age.

The 5 loose herds that did not use additional roughage feeding had 1.7 times greater risk of body lesions on the sows than the herds that used additional roughage feeding (Table 1), however, the difference was not statistically significant $(\mathrm{p}>0.05)$.

\section{Body condition}

About $70 \%$ of the sows were in normal condi- tion and thin sows were not a problem in neither the loose nor the confined herds. The loose herds had a slightly higher average prevalence of fat sows $(16.6 \%)$ than the confined herds $(12.4 \%)$. There was a clear tendency for more fat sows to be present with increasing age in the loose housing herds (Fig. 6). In the herds with confined sows, no such tendency was seen.

\section{Culling reasons}

The culling reasons in the 2 cohorts loose and confined are listed in Table 2. The main culling reasons were nearly the same among loose and confined sows. There was a tendency for higher culling rates due to returns, claw lesions and "poor mother" among loose sows, while empty sows and age/low index were more important culling reasons in confined 


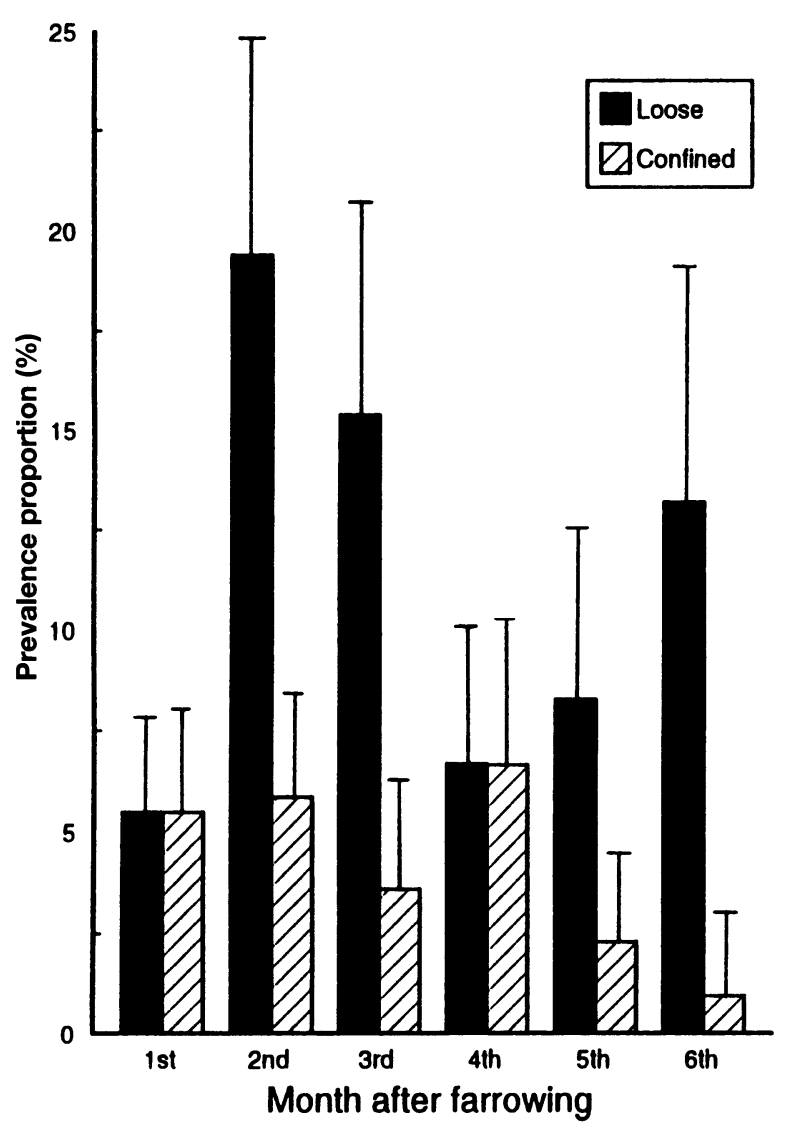

Figure 4. Mean prevalence proportion (with $95 \% \mathrm{CI}$ ) of sows with body lesions in relation to time after farrowing, loose and confıned herds (no. loose sow observations $=1129$, no. confıned sow observations $=1092$ ). However, 307 loose housed pigs were not included in the figure due to not having farrowed (no. gilts $=300$ ) or missing values (7).

than in loose herds. The total culling caused by reproduction failure was the same in the 2 cohorts, however, in the loose herds, returns were the most important category of reproduction failure, while in the confined herds it was empty sows.

The annual culling rate, i.e. the total number of culled sows divided by the total number of year-sows, was slightly higher among loose $(65 \%)$ than among confined (58\%) sows. The average age of the culled sows was lower among the loose sows than among the confined sows. On average, when culled, the loose sows had had 2.3 litters, while the confined sows had had 2.6 litters.

\section{Production results}

The production results for both 1989 and 1990 were very similar in the loose and confined herds (Table 3 ). 
Table 2. Culling reasons in loose $(n=15)$ and confined herds $(n=18)$ based on the farmers' records.

\begin{tabular}{|c|c|c|c|c|}
\hline & \multicolumn{2}{|c|}{ Loose } & \multicolumn{2}{|c|}{ Confıned } \\
\hline & $\begin{array}{l}\text { Number } \\
\text { of sows }\end{array}$ & $\mathbf{P C R}^{1)}$ & $\begin{array}{l}\text { Number } \\
\text { of sows }\end{array}$ & $\mathrm{PCR}^{1)}$ \\
\hline \multicolumn{5}{|c|}{ Reproduction failure: } \\
\hline - Returns & 68 & $17.8 \%$ & 24 & $7.7 \%$ \\
\hline - Empty sows & 43 & $11.2 \%$ & 66 & $21.1 \%$ \\
\hline - No heat & 28 & $7.3 \%$ & 25 & $8.0 \%$ \\
\hline Subtotal & 139 & $36.3 \%$ & 115 & $36.8 \%$ \\
\hline \multicolumn{5}{|c|}{ Locomotor problems: } \\
\hline - Lameness & 51 & $13.3 \%$ & 39 & $12.5 \%$ \\
\hline - Claw lesions & 32 & $8.3 \%$ & 18 & $5.7 \%$ \\
\hline - Black injury & 6 & $1.6 \%$ & 5 & $1.6 \%$ \\
\hline Subtotal & 89 & $23.2 \%$ & 62 & $19.8 \%$ \\
\hline \multicolumn{5}{|l|}{ Performance: } \\
\hline - Small litters & 23 & $6.0 \%$ & 21 & $6.7 \%$ \\
\hline - Poor mother & 19 & $5.0 \%$ & 8 & $2.6 \%$ \\
\hline Subtotal & 42 & $11.0 \%$ & 29 & $9.3 \%$ \\
\hline Age/low index & 24 & $6.3 \%$ & 43 & $13.7 \%$ \\
\hline Other reasons & 89 & $23.2 \%$ & 64 & $20.4 \%$ \\
\hline Total & 383 & $100.0 \%$ & 313 & $100.0 \%$ \\
\hline
\end{tabular}

1) Proportional culling rate (PCR) is the number of culled sows for one reason divided with the total number of culled sows

\section{Discussion}

Vulva lesions were a serious problem in some herds with loose housing of sows, while vulva lesions were not observed in the confined herds. The loose housing herds with additional roughage had a lower prevalence of vulva lesions compared to herds without roughage feeding. Body lesions were seen 3 times more often in the loose herds than in the confined herds.

The positive effect of additional roughage on the frequency of vulva lesions in this study is in accordance with other reports. Feeding of roughage such as straw or hay is known to result in less injuries and aggression (Weber et al. 1991). Van Putten \& van de Burgwal (1990a) showed that daily meals of chopped corn silage reduced the incidence of vulva biting. Straw pellets in the feeding station has also been reported to reduce the number of vulva lesions (Burè 1991). The small quantity of a concentrate diet that meets the sow's physical and reproductive requirement leaves the sow feeling hungry and may result in stereotypic behaviour, both in confined and in loose housing (Lawrence 1991). Fraser (1975) showed that straw reduced the levels of stereotypic behaviour in tethered sows and that straw was important for the sows' expression of feeding motivation. Low feeding levels in loose housing with no roughage feeding can result in a change in social behaviour and aggression (Edwards 1991).

The electronic feeding station with individual feeding of the sow can contribute to aggression and vulva biting (van Putten \& van de Burgwal 1990 a). Vulva biting has most often been seen in the line behind the feeding sta- 


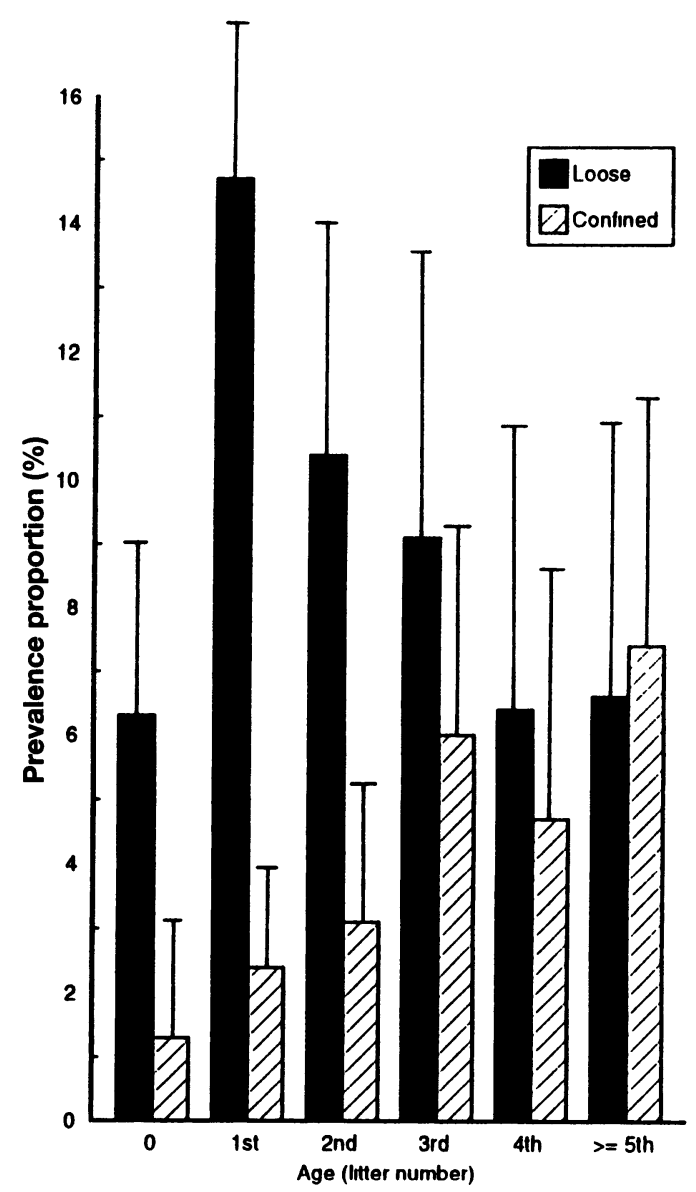

Figure 5. Mean prevalence proportion (with $95 \% \mathrm{CI}$ ) of sows with body lesions in relation to number of litters, loose and confined herds (no. loose sow observatıons $=1436$ no. confined sow observations $=1260$ ).

tion, but can also occur in other situations (Olsson et al. 1991).

The herds with a mechanical hind gate in the feeding station had a higher prevalence of vulva lesions than herds with an electronic hind gate in the present study. This was somewhat surprising, because mechanical hind gates protect the sow while she is standing in the station, but in a station with an electronic hind gate, the hind gate opens after a certain time leaving the sow vulnerable to attack. Be- havioural or functional studies were not performed in this investigation, but Olsson et al. (1991) found that sow-controlled (mechanical) hind gates were associated with longer eating time, more empty visits, more queuing and more conflicts behind the station. This may explain the higher prevalence of sows with vulva lesions in the herds with mechanical hind gate in the present study. Technical problems with the stations may be an important cause of vulva lesions (Olson et al. 1991), 
Table 3. Some production parameters in herds with loose and confıned sows in the 2 years 1989 and 1990.

\begin{tabular}{lccccc}
\hline & \multicolumn{2}{c}{ Loose } & & \multicolumn{2}{c}{ Confined } \\
\cline { 2 - 5 } & 1989 & 1990 & 1989 & 1990 \\
\hline No. of herds & 15 & 15 & $17^{1)}$ & $17^{1)}$ \\
No. of litters & 1090 & 1181 & 1032 & 1148 \\
Live born per litter & 10.8 & 10.9 & 11.0 & 10.9 \\
\% stillborn & 8.1 & 8.2 & 8.3 & 8.2 \\
\% of losses before 3 weeks & 16.3 & 17.3 & 17.1 & 16.4 \\
5 of first litter & 39.2 & 35.9 & 31.7 & 29.6 \\
No. of piglets per year/sow & 18.1 & 18.2 & 18.5 & 18.0 \\
\hline
\end{tabular}

1) One confined herd was due to incomplete records.

however, in the present study there were no reports of serious technical problems with the stations.

Increased prevalence of vulva lesions from the farrowing compartment to the loose housing compartment would be expected when sows moved from individual housing to group housing. The increased prevalence of vulva lesions at the end of pregnancy can probably be explained by the swelling of the vulva and increased mucus secretion in the last weeks before farrowing. There was also possibly a cumulative effect through the pregnancy period. The gilts had less vulva lesions than the sows that had farrowed. This observation could be a result of the low rank order of the youngest individuals and their tendency to stand at the back of the queue at the feeding station. Another explanation could be the small size of the vulva of gilts, which made them less vulnerable for biting. In some herds, one sow could be a "vulva-biter" as with a tailbiter in pens of growing-finishing pigs.

Water in the feeding station has been associated with less vulva lesions (Olsson et al. 1991). It is also reported that feeding once a day leads to less vulva lesions than feeding twice a day (Weber et al. 1991). Less queuing and aggression around the feeding station occur with feeding once a day. In the present study, however, no difference in the frequency of vulva lesions between the herds with or without water in the feeding stations, and no difference between herds that fed once or twice a day was detected.

The causes of vulva lesions that were examined in this study form a range of predisposing factors. However, it is not correct to look at single isolated factors because the risk of confounding from other factors is large. The GLM analysis used in this study reduces the risk of errors due to confounding. The crude herd means of sows with vulva lesions indicated that bar walls in the feeding station were a risk factor for vulva lesions; however, the GLM analysis showed that this was due to confounding influence from other factors, mainly roughage feeding.

The body lesions on sows in the loose herds were mainly caused by interactions between the animals, while the lesions on the confined sows were mainly decubitus lesions. The highest prevalence of body lesions on the loose sows seemed to be during the initial period after they had been released into the loose house compartment. In this period, there are frequent interactions between new sows and sows already in the pen to establish their social ranking (Weber et al. 1991). The weaned sows, most often 3-5 sows together, were re- 


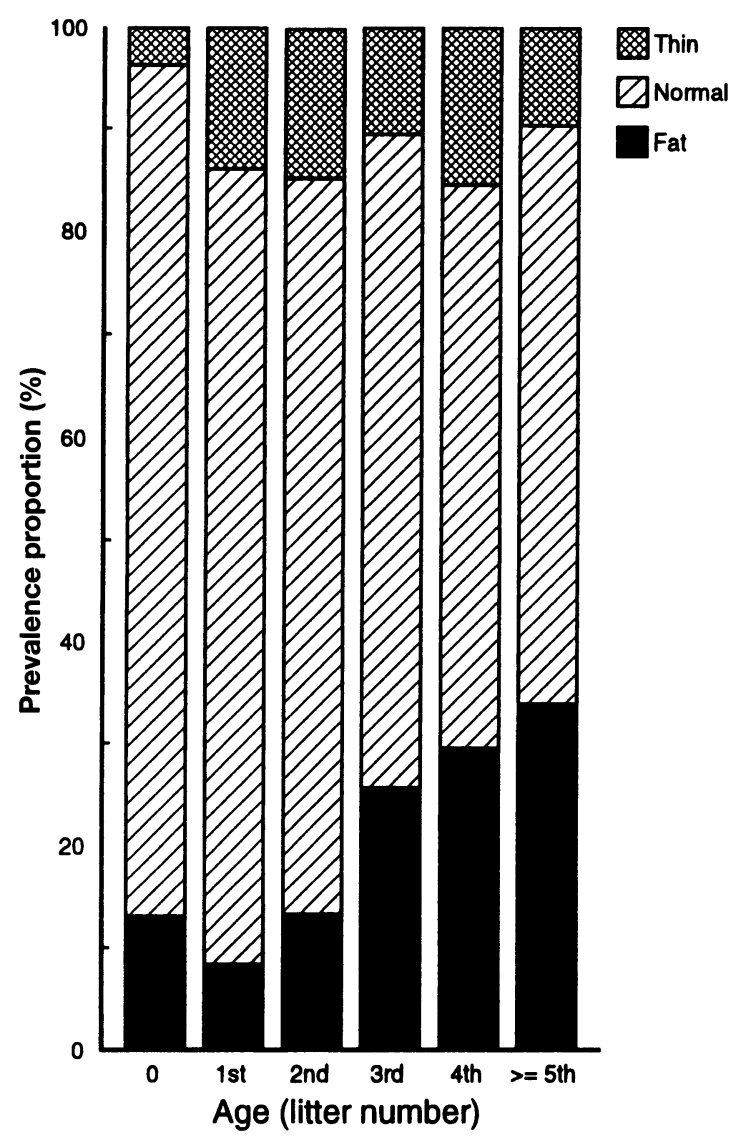

Figure 6 The distributıon of thın, normal and fat sows in relation to number of litters in loose herds (no. loose sow observations $=1436$ ).

leased into the group of pregnant sows after weaning. Thus the social rank order was frequently disturbed. Stable groups with a clearly defined rank order have less interactions than dynamic groups (Edwards 1991). However, integrated loose housing of sows, where the suckling and the pregnant sows are together, has other disadvantages (van Putten \& van de Burgwal 1990b, Bøe 1993). Very large dynamic groups (60-120) can also function well if the sows are trained to use the feeding station and the total space is adequate (Peet 1990).

Straw or other additional roughage did reduce the prevalence of body lesions, however, not to the same extent as for the vulva lesions. $\mathrm{Bo}$ termans (1990) found that straw did not reduce the occurrence of aggression during the grouping of sows.

The highest prevalence of body lesions was found among loose sows that had had 1 or 2 litters. An explanation could be that these 
sows tried to defend themselves when they were attacked by older sows, while the gilts escaped when they were attacked. The variation between loose herds was less with regard to body lesions than with regard to vulva lesions. The instinctive nature of the aggressive interactions between sows to establish rank order may have contributed to the more uniform presence of body lesions and may further indicate that this type of lesions will be more difficult to eliminate (Mount \& Seabrook 1993).

The estimates of cumulative proportion of diseased sows in the herds will always increase as the observation period increases. The observation period was 1 year for all the herds. However, since the 2 cohorts were dynamic, the cumulative proportion was underestimated since many of the sows did not spend the whole year (risk period) in the herd. This underestimation was larger for loose herds than for confined herds because of a higher culling rate in loose than in confined herds, i.e. the estimates of relative risk in loose versus confined herds were conservative. Between the subgroups within the loose herds, this was not a problem because the culling rates were quite similar.

The interactions between sows that lead to vulva and body lesions did not cause a decline in production results. Thus, the differences in welfare between loose and confined herds were not great enough to cause differences in production results. Loss of performance is reported if mixing occurs during the implantation period (Bokma 1990, te Brake \& Bressers 1990). The herds in the present study mixed sows either directly after weaning or 3 weeks after service.

The body condition of the sows did not vary much between loose herds and confined herds. Thin sows have been reported to be a welfare problem in loose housing with feeding stations (Olsson et al. 1991), this was not observed in the present study. However, fat old sows were a problem in some loose herds. The fat sows that were high in the rank order appeared to scare the young sows out of the station and then would eat the rest of the young sows' food. The biggest sows were also able to steal, in one way or another, concentrates in the feeding station, eg. by knocking so hard on the wall that a small amount of concentrate fell into the trough.

The main culling reasons were similar among the loose and the confined sows, although there was some higher culling rate due to locomotor problems in the loose than in the confined herds. The total culling caused by reproduction failure was the same in the 2 types of herds, but in the loose herds, more sows were culled because of returns and less because they were empty, than in the confined herds. The reason for this can be that it was easier to detect a loose sow in oestrus than a confined sow in oestrus. Pregnancy checking was not performed in the herds included in this study. Fighting in the loose herds and subsequent early abortion may also have contributed. It has been reported that the introduction of new sows into a group during the first week after service resulted in $20 \%$ returns, while introduction more than 3 weeks after service only gave $10 \%$ returns (Bokma 1990). The production results were nearly the same in loose and confined herds. This is in accordance with other reports (Bäckstrøm 1973, Hansen \& Vestergaard 1984, Svendsen \& Olsson 1985, Hunter 1990).

Claw lesions may be equally important for welfare in loose housing on partly slatted floors as any of the welfare parameters that are discussed in this paper (de Koning et al. 1990, Gjein \& Larssen 1995).

As a general comment on the testing of statistical associations, one should keep in mind 
that the power in detecting statistically significant associations is small with so few herds. There is a risk of not detecting associations that really exist.

\section{Conclusions}

The present study showed that vulva lesions and body lesions may be important welfare problems in loose housing of pregnant sows on partly slatted floors. Feeding with roughage and correct design of the feeding station were important factors in reducing aggression and vulva biting in the herds with loose housing of pregnant sows.

\section{Acknowledgements}

We thank Nina Lunderød for excellent technical assistance.

\section{References}

Barnett JL, Hemsworth PH, Cronin GM, Newman EA, McCallum TH, Chilton D. Effects of pen size, partial stalls and method of feeding on welfare-related behavioural and physiological responses of group-housed pigs. Appl. Anim. Behav. Sci. 1992, 34, 207-220.

Backstrøm $L \cdot$ Environment and animal health in piglet production. A field study of incidences and correlations. Acta vet. scand. 1973, Suppl.41.

Bokma $S$. Housing and management of dry sows in groups in practice partly slatted systems. Electronic identification in pig production. An international symposium exchanging experience between countries. Stoneleigh, 1990, 37-45.

Botermans JAM: The effect of straw on the aggression of sows during grouping. Swedish Unıversity of Agricultural Sciences Department of Farm Bulldings, Lund, 1990, Report 66, App. 2, 81-96.

Burè $R G$. The influence of additıonal roughage in an electronic sow feeder on vulva biting. Proc. 42nd Ann. Meet. Europ. Ass. Anim. Prod., Berlın, 1991, p.369.

$B \varnothing e K$ : Maternal behaviour of lactating sows in a loose-housıng system. Appl. Anım. Behav. Scı. 1993, 35, 327-338.

de Koning $R$ : On the well-being of dry sows. Thesis. Utrecht, 1985. de Konıng R, Backus GBC,
Vermeer HM: Welfare, behaviour and performance; partly slatted systems. Electronic identification in pig production. An international symposium exchanging experience between countries. Stoneleigh, 1990, 53-62.

Dean AG, Dean JA, Burton AH, Dicker RC: Epi Info, Version 5; a word processing, database, and statistics program for epidemiology on microcomputers. USD, Inc., Stome Mountain, Ga, 1990.

Edwards $S A$ : Scientıfıc perspectives on loose housing systems for dry sows. Pig vet. J. 1991, 28, 4051.

Ekesbo I, Jensen P, Lock $R$ : Några exempel på beteendeforandrıngar vid fixering av sınsuggor. Svensk Vet.-Tidn. 1979, 31, 315-319.

Fraser D. The effect of straw on the behaviour of sows in tether stalls. Anim. Prod. 1975, 21, 59-68.

Gjein $H$, Larssen $R B \cdot$ Housing of pregnant sows in loose and confined systems - a field study. 2 . Claw lesions; the impact of housing factors. 1995. Submitted.

Hansen LL,Vestergaard $K$ : Adfærd og produktion hos oppbundne og løse søer. II Produktionsresultater og sundhedsdata (Behavious and production of tethered and loose sows. II. Production and health results). Dansk Vet.- T. 1986, 69, 319-331.

Hunter EJ. Sow housıng systems. Anımal welfare and production in electronic sow feeding systems compared to other straw-based group-housing systems in the UK. Electronic identification in pig production. An international symposium exchanging experience between countries Stoneleigh, 1990, 47-52.

Kroneman A, Vellenga L, van der Wilt FJ, Vermeer $H M \cdot$ Review of health problems in grouphoused sows, with special emphasis on lameness. Vet. Quart. 1993, 15, 26-29.

Lawrence $A B$ : The effects of different housing systems on sow welfare. Proc. 42nd Ann. Meet. Europ. Ass. Anım. Prod., Berlın, 1991, p.365.

Mount NC, Seabrook MF A study of aggression when group housed sows are mixed. Appl. Anim. Behav. Scr. 1993, 36, 377-383.

Olsson AC, Andersson M, Lenskens P, Rantzer D, Svendsen J: Besattnıngsstudier av olık datorutfodringssystem for draktiga suggor (Herd studies of different electronic dry sow feeding systems). Swedısh University of Agricultural Sciences, Department of Farm Bulldings, Lund, 1991, Report 75. 
Peet $B$. Housing and management in practise - straw bedded systems. Electronic identification in pig production; an international symposium exchanging experience between countries. Stoneleigh, 1990, 25-36.

SAS Institute Inc.. System ver. 6.04 for DOS. SAS Institute Inc., Cary, NC, 1989.

Svendsen J, Andersson M, Olsson AC, Rantzer D, Lundqvist $P$ : Grupphållnıng av draktiga suggor 1 isolerade och oisolerade stallar. En beskrivning av resultaten från enkatundersokningar, gårdsbesok och grupperingsforsok (Group housing of sows in gestation in insulated and uninsulated buildings. Results of a questionnaire survey, farm visits and grouping studies). Swedish Unıversity of Agricultural Sciences, Department of Farm Buldıngs, Lund, 1990, Report 66.

Svendsen J, Olsson AC. Innhysningssystem for draktiga och grisande/digivande suggor for at minska spadgrisforlustarna (Housing system for pregnant, farrowing/laclatıng sows that reduce neanetal mortality). Swedish University of Agrıcultural Sciences, 1985, Fakta Teknık 16.

te Brake JHA, Bressers HPM: Applications in service management and oestrus detection. Electronic identification in pig production. An international symposium exchanging experience between countries. Stoneleigh, 1990, 63-67.

van Putten $G$, van de Burgwal JA, $a$. Vulva biting in group-housed sows: preliminary report. Appl. Anım. Behav. Sci. 1990, 26, 181-186.

van Putten $G$, van de Burgwal JA, $b \cdot$ Group housing systems for farrowing and lactatıng sows. Proc. of a seminar organised by the European Conference Group on the Protection of Farm Anımals. Brussels, 1990, 65-78.

Weber R, Friedll K, Troxler J: The influence of the computerised feeding on the behaviour of sows and its effects with regard to injuries and alterations on their body. Proc. 42nd Ann. Meet. Europ. Ass. Anim. Prod., Berlın, 1991, p.367.

\begin{abstract}
Sammendrag
Løsgående og fikserte gjeldpurker - en felt studie. 1 . Vulva- og kroppssår, utsjalttngsårsaker og produksjonsresultater.
\end{abstract}

En feltunders $\emptyset$ kelse ble utf $\varnothing$ rt 118 besetninger med løsgående gjeldpurker og i 18 besetnınger med fikserte og oppbundne purker. Femten av løsdrifts-besetningene hadde betonggulv med spalter og transponderfôring. Tre besetninger hadde en annen type gulv, de ble ekskludert 1 denne del av studien. Vulvasår forekom kun 1 besetnınger med løsdrift av gjeldpurker, den gjennomsnittlige prevalensen 1 besetnıngene var $15.2 \%$. Årsaken til vulvasår var 1 hovedsak biting. Den relatıve rısiko for vulvasår var 2.6 ganger høyere 1 besetninger som 1 kke brukte grovfôr enn 1 besetnınger som hadde appetitt fôrıng med grovfôr. Det var 1.8 ganger høyere relativ risiko for vulvaskader i besetnınger med mekanısk lukkıng av bakporten på fôrıngsstasjonen sammenlıgnet med besetninger med elektronisk bakport.

Den gennomsnittlige prevalensen av purker med sår på kroppen var $131 \%$ i løsdrıftsbesetnıngene og $4.0 \% 1$ de konvensjonelle besetnıngene. Hovedårsaken tıl sår hos de løse purkene syntes å være slåssing, mens liggesår var hovedårsaken hos fikserte og oppbundne purker. Det var flest purker med sår på kroppen 1 løsdriftsbesetnıngene som 1kke brukte grovfôr.

Det var små forskjeller mellom de to oppstallingssystemer når det gjaldt utsjaltingsårsaker og produksjonsresultater.

Denne feltundersøkelsen viste at løsdrift av purker kan føre til visse velferds-messige problemer for dyra, bla. vulvaskader og slåssing. Ved bruk av grovfôr, rıktıg innredning og godt stell kan disse problemene reduseres vesentlig.

(Recelved June 1, 1994, accepted January 26, 1995).

Reprints may be requested from: H. Gjeın, Central Veterınary Laboratory, PO. Box 8156, Dep. N-0033 Oslo, Norway. 